\title{
Instrumentalização do riso: entre brechas e confins A personagem do pastor Adélio
}

\author{
Instrumentalization of the laughter: Between breach and \\ boundaries - The character of the "Pastor Adélio"
}

Patrícia Leonor Martins ${ }^{1}$

Pois de muitas coisas agora já podemos rir. De outras jamais poderemos. Millôr Fernandes

\section{Resumo}

O presente artigo trata do riso no cristianismo, para tanto foi necessário optar por uma metodologia que pudesse dar conta de identificar o tipo de humor apresentado pela personagem do Pastor Adélio, seus limites e intersecções com o sagrado cristão e o humor. Assim, estabeleceu-se como critério metodológico usar a definição de paradigma desenvolvia na obra Signatura Rerun, de Giorgio Agamben. Também far-se-á uso da definição desenvolvida em artigo intitulado Em Nomes de lugar: confim de Massimo Cacciari, em que o autor desenvolve o conceito de confim e sua ligação com as aporias da contemporaneidade "globalizada". O que se propõe nesse artigo é identificar no discurso as lacunas, "brechas" encontradas pelo humorista nos textos bíblicos, bem como no contexto sócio-político-religioso da atualidade brasileira constatando as formas humorísticas utilizadas a partir de paradigmas. Para tanto, será feito uma análise nas falas da personagem à luz do conceito de confim, soleira, entrelugar, e assim identificar no discurso as "brechas" encontradas pelo humorista nos textos bíblicos, bem como no contexto sócio-político-religioso da atualidade brasileira retratando as formas humorísticas utilizadas.

Palavras-Chave: Brechas, Confins, Ciberateísmo, Partor Adélio

\footnotetext{
${ }^{1}$ Graduada em Letras - Língua Portuguesa e Literaturas de Língua Portuguesa pela Universidade Federal de Santa Catarina (UFSC), no ano de 2005. Possui Mestrado em Literatura pela UFSC (2017). É Doutoranda no Programa de Pós-Graduação em Literatura (PPGLit) na Universidade Federal de Santa Catarina - UFSC, com ênfase na área de Textualidades Hibridas - bolsista CAPES. É pesquisadora do NUTEL - Núcleo de Estudos comparados entre Teologia e Literatura.
} 


\section{Abstract}

The present article deals with laughter in Christianity, so it was necessary to choose a methodology that could account for identifying the type of humor presented by the character of Pastor Adelio, its limits and intersections with the sacred Christian and humor. Thus, it was established as a methodological criterion to use the definition of paradigm developed in the work Signatura Rerun, by Giorgio Agamben. The definition developed in an article titled In Names of Place: confim by Massimo Cacciari, in which the author develops the concept of confim and its connection with the aporias of the "globalized" contemporaneity, will also be used. What is proposed in this article is to identify in the discourse the gaps, "gaps" found by the comedian in the biblical texts, as well as in the socio-political-religious context of the Brazilian reality, noting the humoristic forms used from paradigms. To do so, an analysis will be made in the speeches of the character in light of the concept of confim, threshold, interlace, and thus identify in the discourse the "gaps" found by the comedian in the biblical texts, as well as in the socio-political-religious context of the Brazilian reality portraying the humorous forms used.

Keywords: Gaps, Confins, Cyberathism, Parel Adélio

\section{Entre brechas e confins: onde circula uma personagem}

Massimo Cacciari é o filósofo italiano que nos apresenta, em seus estudos, o conceito de linde, fronteira, confim. Observemos o que o filósofo afirma:

Confim se pode dizer de muitas maneiras. Em geral, o termo parece indicar a "linha" ao longo da qual dois domínios se tocam: cum-finis. Dessa forma, o confim distingue, tornando comum; estabelece uma distinção determinando uma ad-finitas. Fixado o finis (e em finis ressoa provavelmente a mesma raiz de figere), "inexoravelmente" se determina um "contato". Mas - antes de desenvolver essa idéia essencial, que concresce na nossa linguagem - entendemos por confim limen ou limes? O limen é a soleira, que o deus Limentinus guarda, o passo através do qual se penetra em um domínio ou se sai dele. Através da soleira, somos acolhidos ou eliminados. Ela pode se dirigir ao "centro", ou abrir para o limite, para aquilo que não possui forma ou medida, "onde" fatalmente nos perderíamos. Limes é, ao invés, o caminho que circunda um território, que engloba sua forma. Sua linha pode ser oblíqua, por certo (limus), acidentada, todavia, ela equilibra, de uma certa forma, o perigo representado pelas soleiras, pelos passos, pelo limen. $(2015,13-14)^{80}$ 
O que se pode perceber é que para Cacciari, o confim é um conceito paradoxal porque não há como pensar o espaço fora do confim. Assim como não é possível pensar a literatura fora da dimensão contingente dos intercâmbios com outras disciplinas. Por exemplo, no meio acadêmico há muitas vezes o movimento entre diversas disciplinas que buscam novas formas de se conceituar ou de definir o seu objeto por meio da relação com outras disciplinas. Em suma, a questão fundamental não é o fim, o objetivo ou meta da construção, mas seu confim, que pode ser dito de várias maneiras. Para Cacciari, nenhum confim pode eliminar ou excluir o outro, pois este está também na sua própria essência. Na maior parte dos casos, conforme assinalado anteriormente, o termo parece indicar a "linha" ao longo da qual dois domínios se tocam: com- finis "Mas o fim é com-fim, o contato com o outro. O extremo limite de um ente, isto é, que maximamente o define, é também comum, o que ele tem de essencialmente comum com o outro em si" (p.17).

Silveira (2015, p. 64), também fez uso da definição de soleira em sua dissertação, vejamos o que ele nos diz:

Esta porta aberta faz com que esse limite seja também aberto, ele
transita, ele atravessa a fronteira da soleira e se deixa contaminar
com o lado oposto. Ali na soleira está o confim, conceito
apresentado por Cacciari, que nos diz que "o termo parece
indicar a 'linha' ao longo da qual dois domínios se tocam"
(CACCIARI, 2015, p. 13). Essa linha de contato, essa intersecção,
esse confim, esse entrelugar, é o ambiente da soleira que permite
a fluidez, onde a relação entre dois ambientes, dois corpos, dois
lugares, duas ideias, se estabelece. É o contato entre o outro lado,
o lado oposto a esse outro lado e, consequentemente, o choque
de ambos. O objeto é contaminado e vai se tornar contaminador.
Não existe uma fronteira fixa, estanque e limítrofe. "Não são os
corpos a transgredir, mas é o próprio confim que sempre
transgride. (...) O confim não é transgredível, pois é
transgressão" (CACCIARI, 2005, p. 18).

Em análise, a ideia central do confim é essa intersecção que se faz nas fronteiras e que vai mudando os sujeitos, ou seja, o sujeito que ao tocar o limite 
Religare, ISSN: 19826605, v.15, n.2, dezembro de 2018, p.585-611.

deixa de ser o mesmo sujeito, ele passa a ser outro, em suma, ele sempre é contaminado. Por exemplo, a cultura gaúcha, ela é uma cultura brasileira ou é uma cultura hispânica? Ela está em um entrelugar, pois a cultura gaúcha é uma cultura de fronteira, entre um território colonizado por espanhóis e um território colonizado por brasileiros, aí ela traz elementos das duas culturas, ela está contaminada. Até a língua é hibrida, criando uma identidade própria, uma assinatura. Ainda que as fronteiras não existam, o fim é o confim, o contato com o outro, o toque, o que toca, o exato instante em que se define onde começa um e termina o outro é o momento em que eles se tocam, e que aconteceu a contaminação. Para Cacciari, nenhum confim pode excluir o outro, pois esse está sempre em sua própria essência.

Então, justamente nesse lugar, nesse limite, que se encontram as brechas, as lacunas no texto bíblico, que o humorista Marcio Américo, na personagem do Pastor Adélio, vai se agarrar e buscar o humor. Essas brechas se dão muito nos dogmas que as religiões constroem, que não são nem teologia, nem literatura. Nesse aspecto, o humorista tenta ultrapassar as barreiras para preencher os espaços de contato.

$\mathrm{Na}$ personificação da personagem do Pastor Adélioº $^{2}$ a caracterização, a performance, utilizada pela personagem para dar vida ao Pastor mais sincero do mundo, está no entrelugar para com o Pastor da vida real, aquele que conhecemos dos cultos e pregações, tanto na TV quanto na Internet. Esse entrelugar será o ponto de contaminação, momento em que ambos estarão dentro e fora ao mesmo tempo.

\footnotetext{
2 A personagem do Pastor Adélio que fora criada pelo humorista paranaense, da cidade de Londrina, Marcio Américo Alves um ciberateísta - pessoa que utiliza as redes mundial de computadores para manifestar a sua descrença e ou contestar a crença do outro. Marcio diz que suas leituras sobre religião, em especial sobre as seitas pentecostais e neopentecostais, fizeram com que resolvesse discutir o assunto de maneira mais ostensiva, usando as ferramentas digitais e que naturalmente acabou chegando à personagem do pastor. Mais sobre o Pastor Adélio pode ser lido em dois artigos pulicados por mim na Revista Teoliterária Intitulados: a) A arte do humor: "Pastor Adélio, o pastor mais sincero do mundo" (2016, p. 287 - 312) : https://revistas.pucsp.br/teoliteraria/article/view/2236-9937.2016v6n11p287-312/20175;

Ciberateísmo: religião e ateísmo em tempos de rede $(2018$, p. 266 -296) https://revistas.pucsp.br/teoliteraria/article/view/33009/26009.
} 
Religare, ISSN: 19826605, v.15, n.2, dezembro de 2018, p.585-611.

Um pastor personagem, fictício, mas que fala a verdade. Esse que tem todas as características de um pastor real, aquele que adentra um espaço sagrado, a Igreja, a casa do espectador/fiel, aquele que faz uso de indumentárias vistas como as mais adequadas para um ser considerado "divino", pois fora "enviado por Deus para proferir a sua palavra" ${ }^{3}$. Todas essas características são encontradas facilmente nos pastores da vida real. Ambos estão caracterizados dentro de um ambiente personificado, são pastores. No entanto, o pastor fictício, Pastor Adélio, aparece para uma espécie de retirada do véu da encenação daquele pastor da vida real. Os pastores são performáticos, só que eles realizam uma performance que pretendem que seja vista como verdadeira, como fidedigno. Então o Pastor Adélio desconstrói isso, diz abertamente aquilo que supostamente seria a real intenção de um pastor. Mas como ele faz isso? Ele se agarra nas brechas fornecidas pela própria Bíblia para falar da religião e da sociedade. Para isso, faz uso de uma língua muito afiada ${ }^{4}$, composta de muita ironia e de um humor satírico para escancarar uma suposta verdade. Coloca-se como um pastor, pois também fala com seus fiéis, só que em um humor sarcástico e irônico. $O$ verdadeiro Pastor é o Adélio, pois esse não engana, seu fiel logo percebe a sua intenção, ganhar dinheiro. Então ele é um não-pastor, pois só fala a verdade.

Agora, ao observarmos o texto bíblico utilizado pelos pastores, os da vida real e o fictício, criado pelo humorista, vamos observar que ambos utilizam o mesmo discurso de referência, a Bíblia. No entanto, a interpretação dada por cada um dos pastores é que se diferem. Muitos são os pastores da vida real que mantém o texto de forma religiosa, canônica, dentro de suas visões e interpretações, pregam a "palavras de Deus", a fim de convencer os seus fiéis, em função de uma determinada intenção. Outrossim, é preciso pontuar que nem todos os pastores são assim, poucos, mas não raros, são os que de fato levam a

\footnotetext{
3 O próprio Marcio Américo afirma em entrevista concedida a mim durante pesquisa de mestrado, que pode ser lida na dissertação defendida em 2017 pela UFSC, intitulada: Ciberateísmo: sátira e humor na personagem do pastor Adélio disponível em: https://repositorio.ufsc.br/handle/123456789/177782.

${ }^{4}$ Basta observarmos a quantidade de palavrões ditas pela personagem.
} 
Religare, ISSN: 19826605, v.15, n.2, dezembro de 2018, p.585-611.

religião a sério, e pregam a "palavra de Deus" acreditando realmente no texto bíblico.

Já, o Pastor Adélio, embora faça uso exatamente das mesmas artimanhas que o pastor neopentecostal e pentecostal, da nossa sociedade, no sentido de convencimento do fiel, ele vai fazer uma exegese do texto bíblico com a intenção de desconstruir o próprio pastor, desconstruir a própria religião, a seriedade dela. Ele usa a religião com objetivos profanos. No entanto, não é isso que muitos pastores fazem?? Usar a religião para enriquecer? Usar a fé do outro para aumentar o seu poder? Só que o pastor da vida real não diz isso, e é aí que o a personagem do Pastor Adélio se torna o pastor mais sincero do mundo, como ele mesmo se intitula, pois ele fala exatamente aquilo que o outro faz. Nesse caso os pastores estão em um entrelugar, pois o pastor Adélio vai "vestir a casaca" para dizer tudo aquilo que o pastor da vida real não pode, não deve e, muitas vezes, não quer dizer, e não diz! Quando o Pastor Adélio fala o que o outro não diz ele sai da soleira, ele está dentro e fora ao mesmo tempo. É nessa linha de análise que o estudo realizado com os dois esquetes de repercussão midiática criados pelo humorista, dando voz à personagem do Pastor Adélio, será estudado.

O humorista Marcio Américo dá voz ao Pastor Adélio através do vídeo intitulado Ló e suas Filhas Taradas, postado em 2012, publicado na página do YouTube e posteriormente linkado na rede social Facebook, página da personagem. Aqui apresenta-se a análise desse vídeo, terceiro de maior repercussão, que está atualmente com 361.614 mil visualizações, no vídeo o Pastor Adélio fala da passagem bíblica de Gênesis 19, 30-38. O Segundo vídeo da análise é o intitulado Detonando os Ursinhos Carinhosos, publicado em 2013, que está com 115.583 mil visualizações. O foco central das análises será estabelecido pelo aspecto do risível juntamente com os conceitos de: ironia, sátira, paradigma e confins, enquanto métodos de análises. Portanto, busca-se retratar na transcrição dos vídeos e das perícopes bíblicas a dessacralização do texto tido como sagrado, bem como a apropriação paradigmática do texto bíblico pela personagem do Pastor Adélio para transformá-lo em humor por meio das 
Religare, ISSN: 19826605, v.15, n.2, dezembro de 2018, p.585-611.

lacunas, confins e soleiras encontradas entre as passagens bíblicas e o discurso da personagem.

Outro ponto importante a ser observado é a questão do paradigma utilizado pelo humorista ao tratar do riso no cristianismo, nesse sentido utiliza-se como critério metodológico a definição de paradigma desenvolvia na obra Signatura Rerun, de Giorgio Agamben, a qual mostra ao leitor que é possível escolher o que se quer como referência de paradigma, que mesmo optando por um método não necessariamente é preciso negar o outro. Assim, foi possível identificar o tipo de humor apresentado pela personagem do Pastor Adélio, seus limites e intersecções com o sagrado cristão e o humor.

No primeiro capítulo intitulado Paradigma da obra Signatura Rerun, de Giorgio Agamben ${ }^{5}$ o leitor vai conseguir distinguir entre a teoria que é referente a Foucault e o que deve atribuir- se ao autor ou aquilo que serve para ambos. Para Agamben (2010), paradigma é um método de análise, é o que não está dito, mas pode estar desenvolvido, para ele só se consegue avaliar um objeto de estudo se for possível ter a análise arqueológica do que já foi estudado e do que foi encontrado, mas que ainda não foi dito e que está na obra. O objeto de análise não muda, o que muda é o foco e ele se renova ao mesmo tempo que essa arqueologia do saber se refaz ao longo do tempo. É o olhar do pesquisador enquanto leitor que se renova, que passa a olhar para trás e encontrar novos "rastros" e indícios.

Agamben vai mostrar ao leitor que é possível escolher o que se quer como referência de paradigma, o autor afirma que dentro de um paradigma tem uma questão fundamental, que é o que eu uso como paradigma. Para ele, paradigma e análise nada mais é do que uma comparação, como uma analogia. A analogia, bem ou mal, ela é feita a partir do momento em que se está analisando "aquela obra", porque a realidade, mesmo científica, muda. As descobertas mesmo

573 AGAMBEN, Giorgio, Signatura Rerun, 2010. Disponível em htps./joaocamillopenna.files.wordpress.com/2013/08/agamben-giorgio-signatura-rerum.pdf.

Acessado em: 23/12/2018. 
Religare, ISSN: 19826605, v.15, n.2, dezembro de 2018, p.585-611.

dentro do método científico acontecem. Quando é feito a análise a partir do momento em que está inserido o "meu olhar muda".

Assim, para Agamben, "construir e fazer inteligível a totalidade de um contexto histórico-problemático mais vasto" (AGAMBEN, 2010, p.11; tradução livre) trata-se de paradigma, que pressupõe o abandono particular-geral para elaborar discursos como articulações históricas de paradigmas. Permitindo-se construir contextos e conjuntos a partir de um sentido próprio, o paradigma seria como um objeto singular que define a inteligibilidade do conjunto de objetos de uma mesma classe, do qual forma parte e que, ao mesmo tempo, constitui. Para o autor, o paradigma não é simplesmente um exemplo e tão pouco modelo,

[...] um exemplo é, então, um ato complexo que supõe que o termo oficializa o paradigma é desativado de seu uso normal não para ser envolve o termo paradigma oficiante é desativado de uso normal não ser movido para outra área, mas pelo contrário, para mostrar o cânone daquele uso, que não é possível exibir de outra maneira. (AGAMBEN, 2010, p. 23-24. Tradução Livre)

Nessa acepção, pressupõe que o termo que anuncia o paradigma se desloca de seu modo habitual "para mostrar o cânone daquele uso, que não é possível existir de outro modo" (ibidem, p. 24). Sendo assim, pode-se dizer que não há uma transcendência da figura paradigmática, pois ela vai de singularidade a singularidade, apenas, sem esquivar-se do que diz, sem deixar de constituir-se de parte daquilo que comunica. (AGAMBEN, 2010, p, 29).

O paradigma, como método, trata de pinçar eventos, ideias que iluminem uma "face" do objeto investigado que está ou não obscurecida na mira da história. É nesse aspecto que tomar-se-á o significado de paradigma para analisar a personagem do Pastor Adélio. ${ }^{6}$

\footnotetext{
${ }^{6}$ Para maior aprofundamento sobre a temática dos paradigmas sugiro a leitura de minha dissertação de mestrado.
} 


\title{
Pastor Adélio: ló e suas filhas tarada e detonando os ursinhos carinhosos: análise
}

\author{
Pastor Adélio: Ló e Suas Filhas Taradas
}

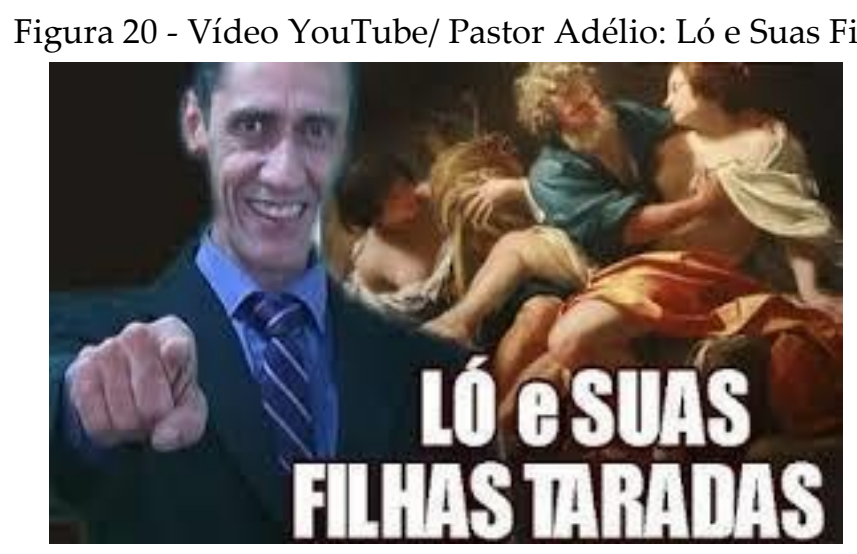

Fonte: Disponível em: http://www.youtube.com/watch?v=y9g-YmLsgxE. Acesso em: 23/12/2018.

Américo faz uma interpretação alternativa, heterodoxa, livre. O humorista dessacraliza o texto. Nessa dessacralização, o "Pastor Adélio" apresenta o texto como uma obra não divina, mas sim humana, que tem uma intencionalidade, ele tenta mostrar essa intencionalidade que existe no texto, que é religiosa e ao mesmo tempo de dominação por parte de grupos religiosos. Mostra que assim como há uma intepretação que é feita pelos líderes religiosos é possível se fazer outra, coerente, lógica, só que tirando do texto a sacralidade que ele tem originalmente.

Para tal, a personagem vai utilizar técnicas humorísticas. Nesse sentido, o Pastor Adélio é o tipo de personagem Caricatura que são aquelas personagens que têm uma qualidade ou ideia única dilatada ao máximo, provocando o exagero de algum traço até à distorção proposital, geralmente, desencadeando uma sátira, como é o caso da personagem do Pastor Adélio - o "Pastor mais sincero do mundo". Dessa forma, o autor, com uma crítica feroz, se dirige aos televangelistas por meio de artifícios cômicos, satíricos e irônicos. 
Religare, ISSN: 19826605, v.15, n.2, dezembro de 2018, p.585-611.

Como em todos os vídeos, o Pastor aparece em um cenário que representa um local imaculado. A personagem se dirige aos fiéis/cristãos inicialmente de forma calma e com tom de voz mediado, mas repentinamente o tom muda e os palavrões aparecem. Sempre com uma música de fundo. A personagem, em seu discurso de pregação, utiliza elementos que despertam o caráter cômico. Por esse ângulo, a comicidade dirige-se a inteligência pura, e não à emoção, como afirma Bergson (1980). A comédia tem em comum com o drama e, a fim de distinguir-se dele, de nos impedir de levar a sério a ação e de nos preparar para rir, utiliza um meio cuja fórmula assim expressa: em vez de concentrar nossa atenção nos atos, ela a dirige mais para os gestos.

A personagem se apresenta como uma caricatura do falso profeta, que usa a força da tradição religiosa sobre a credulidade, ao mesmo tempo ingênua e ambiciosa do público, para tirar proveitos pessoais. É engraçado também o fato de ele deixar bem claro que não acredita em nada, que está enganando mesmo. Há momentos em que se dirige ao povo crédulo, e outros que se dirige aos pastores da sua igreja para ensiná-los a ludibriar e explorar com eficiência o público. A paródia aparece aí, quando ele parodia a performance de alguns pastores pentecostais e neopentecostais da vida real. Ao apresentar com nitidez a realidade vivenciada na sociedade atual, transpondo o texto bíblico, utilizandoo como um pretexto para chocar a sociedade e, ao mesmo tempo, denunciar uma realidade concreta presente em algumas igrejas pentecostais e neopentecostais ele faz uso das características do humor.

No discurso do Pastor Adélio é possível observar a presença de elementos que estão separados, dispersos, fechados em si mesmos, como por exemplo, o sagrado e o profano, o alto e o baixo, o sublime e o insignificante, a sabedoria e a tolice. Os elementos que representam o sagrado e o profano: para ilustrar, transcrevo abaixo, primeiramente, um trecho do referido texto bíblico e, paralelamente, o texto do vídeo A verdadeira história de Ló: 
Religare, ISSN: 19826605, v.15, n.2, dezembro de 2018, p.585-611.

\section{Bíblia de Jerusalém: Gênesis 19, 30-387}

30 Ló subiu de Segor e se estabeleceu na montanha com suas filhas, porque não ousava continuar em Segor. Ele se instalou numa caverna, ele e suas duas filhas. 31 A mais velha disse à mais nova: "Nosso pai é idoso e não há homens na terra que venha unir-se a nós, segundo o costume de todo o mundo. $32 \mathrm{Vem}$, façamos pai beber vinho e deitemo-nos com ele; assim suscitaremos uma descendência de nosso pai. 33 Elas fizeram seu pai beber vinho, naquela noite, e a mais velha veio deitar-se junto de seu pai, que não percebeu nem quando ela se deitou, nem quando se levantou. 34 No dia seguinte, a mais velha disse à mais nova: "Na noite passada eu dormir com o meu pai; façamo-lo beber vinho também nessa noite e vai deitar-se com ele; assim suscitaremos uma descendência de nosso pai." 35 E elas fizeram seu pai beber vinho também naquela noite, e a menor deitou-se junto dele, que não percebeu nem quando ela se deitou, nem quando se levantou. 36 As duas filhas de Ló ficaram grávidas de seu pai. 37 A mais velha deu à luz um filho e chamou Moab; é o antepassado dos moabitas de hoje. 38 A mais nova deu também à luz um filho e o chamou Bem-Ami; é o antepassado dos BenêAmon de hoje.

\section{Pastor Adélio:}

Agora vem a cereja da história, meu irmão. Tão lá, Ló e as duas filhinhas virgens dele, morando na caverna, uma caverninha do $\mathrm{BNH}$, modestinha. Aí as filhas pensam assim: minha querida irmã, estamos só eu, você e nosso pai aqui, a nossa geração vai acabar aqui. Aí a outra teve uma ideia. Não vai não, a gente trepa com o papai e tem um filhinho dele. Olha que coisa abençoada, meu irmão, que lindo pra por nas escolas pras crianças, não é? Olá que coisa de Deus..

Percebe-se que o autor retira a imagem de Deus de sua simbologia original (o sagrado) do contexto religioso, para colocá-la na instância do profano, através da sexualidade. O Pastor Adélio dessacraliza o texto bíblico para compor a esquete virtual e alcançar o público. Nessa dessacralização, a personagem se utiliza de um novo paradigma para o texto religioso, paradigma esse que está imbuído em seu conhecimento de mundo, um mundo atual, uma sociedade atual.

\footnotetext{
${ }^{7}$ Bíblia de Jerusalém, Paulus, 4ª impressão, 2006. SP. p. 59 ( Gênesis 19, 30-38)
} 
Religare, ISSN: 19826605, v.15, n.2, dezembro de 2018, p.585-611.

Giorgio Agamben, ao mencionar Foucault, afirma que a teoria para ser validada precisa ter uma relação de poder, o poder de validação da teoria está no saber constituir conjuntos de proporções aceitáveis. Ou seja, o poder de argumentação que envolve uma nova teoria é importantíssimo para que ela sobreviva. Para o autor, uma teoria pode ser aceita no meio científico se a argumentação for coerente e aceitável. O Pastor Adélio parece ir ao encontro do que afirma Agamben, pois, no vídeo analisado, o pastor utiliza na sua argumentação saberes já conhecidos pelo seu ouvinte/interlocutor, para traçar um paralelo com a história que está posta na Bíblia.

Com a construção de novos saberes a partir dos já existentes que o humorista Marcio Américo age como um narrador ao articular o texto histórico - texto bíblico - em um novo tempo - a atualidade - a um novo paradigma que ele começa a desvendar. O humorista busca estabelecer um fio de sentido que organiza as informações apresentadas e, nesse processo de mobilização de saberes, ele explica ao mesmo tempo em que narra.

Aproximar o ouvinte em um nível mais pessoal, mais atual, faz parte da retórica do humorista. Com isso está diminuindo a distância entre ele, na personagem do Pastor Adélio, e os seus ouvintes/interlocutor. Dessa forma, o humorista realiza um movimento de comparação entre o passado e o presente, o velho e o novo, para tornar compreensível o discurso que ele constrói, tendo este como paradigma a ser transposto, e ao fazer isso ele diminui a distância entre o estranho e o familiar com os seus ouvintes. A singularidade, que marca um paradigma, está perceptível na personagem, a partir do momento que ela o torna diferente do habitual, diferente do pastor da vida real, daquele que encontramos nos cultos.

Para Agamben, o conjunto paradigmático não está jamais pressuposto aos paradigmas, mas permanece imanente a eles. Isso quer dizer que a singularidade não é uma aberração, ela faz parte de um conjunto no qual se destaca, se torna única. Sendo assim, parece-nos que o entendimento de Agamben sobre paradigma se encaixa como método para analisar o vídeo em questão. Assim, 
Religare, ISSN: 19826605, v.15, n.2, dezembro de 2018, p.585-611.

para o pensador italiano "[...] el paradigma es un caso singular que se aísla do contexto del que forma parte sólo en la medida en que, exhibiendo su propia singularidad, vuelve inteligible un nuevo conjunto, cuya homogeneidad él mismo debe constituir" (AGAMBEN, p. 23).

A personagem do Pastor Adélio, faz uso da arte do discurso para concretizar a dessacralização do texto bíblico. Utiliza a língua de forma cômica, no entanto, para Propp a língua não é cômica somente por si só, mas porque reflete a imperfeição do raciocínio de quem fala: “a língua constitui um arsenal muito rico de instrumento de comicidade e zombaria" (PROPP, 1992, p. 119). Destaca-se os trocadilhos, os paradoxos e as tiradas, bem como algumas formas de ironia, como instrumentos linguísticos mais importantes da comicidade. Isso tudo pode ser visto na fala do Pastor Adélio ao contrapor o texto bíblico com a apropriação de sentido dada por ele, e até pela sociedade, sobre o texto original. Como o pastor mesmo diz: "tá na Bíblia, tá escrito lá..."; "provo o que digo com a Bíblia".

Outro recurso para o riso é a ironia, muito utilizada para exprimir o contrário do que se pensa ou sente, no entanto, embute na mensagem vestígios da real intenção do emissor, de modo que o receptor perceba. Nessa premissa, é visível a presença da ironia na pregação da personagem do Pastor Adélio como no percurso narrativo da produção do vídeo. Segundo Muecke (1995), a arte é elevada por meio da ironia, como uma forma de valorização do indivíduo, capaz de sustentar altivamente sua voz na literatura, que através da ironia não vê mais a obra como uma simples imitação, mas, sim, a vislumbra como um produto da realidade. E é nessa linha de pensamento que se insere o autor Marcio Américo ao criar a personagem do Pastor Adélio, pois tenta, por meio do esquete virtual, apontar uma degradação do texto bíblico transformando-o em um pré-texto para a sua pregação, que tem a função de chamar a atenção do seu expectador para a realidade nos programas televisivos e nos vinculados aos canais virtuais através da internet. 
Religare, ISSN: 19826605, v.15, n.2, dezembro de 2018, p.585-611.

Nesse aspecto, percebe-se que há diferentes tipos de procedimentos irônicos utilizado pela personagem do Pastor Adélio, que se englobam e se comunicam, em que seu arranjo textual articula elementos linguísticos que, uma vez relacionados tendem a corroborar para sua finalidade irônica. Isso fica perceptível na "pregação" do Pastor Adélio no esquete virtual:

[...] E mandou um anjo lá pra salvar Ló, porque Ló ele não ia destruir, Ló e a família dele ia salvar porque era gente boa, decente, tinham votado no Kassab, não, não vou matar o Ló. [...]

[...] Vocês querem comer o cu do anjo, não façam isso, eu tenho uma proposta pra vocês, [..] fiquem com minha filha que é virgem, tá aqui minha filhinha, vem aqui [..] ficar com os meninos de Sodoma. Olha que pai amoroso, meu irmão. Qual que era o sobrenome de Ló? Nardoni?

[...] Onde elas acharam vinho nessa caverna?

\section{Compraram no Zé Colmeia?[...]}

[...], ela deu vinho ou uma maconha pra esse velho?[...]

O uso do palavrão no discurso do pastor também tem uma função cômica, em virtude de ser uma prática interditada pelas igrejas aos fiéis, um pecado ${ }^{8}$. Assim, ao empregar repetidamente os palavrões, o pastor demonstra, e deixa clara sua posição nada religiosa, sua falta de fé e temor, que procura cinicamente impor aos fiéis. Percebe-se na "pregação" do Pastor Adélio, observando o excerto acima, uma inquietação irônica que transcende aquilo que se vivencia e o que a imaginação e inspiração criam. Contudo, por meio da apropriação do texto bíblico de forma inteligente, transformando-o em um pré-texto, o humorista Marcio Américo, na personagem do Pastor Adélio, com sua expressão altiva, cheia de desdém, provocações, sarcasmo, ironia, com um fulgor luciférico, conduz com mestria a sua arte, representando-a como uma imitação da vida.

8Para aprofundar temática sugiro a leitura do livro Teologia do Riso: humor e mau humor na Bíblia e no Cristianismo, de Ferraz, Salma; Martins, Patrícia Leonor; et al (org). Campina Grande - EDUEPB: 2017. 
Religare, ISSN: 19826605, v.15, n.2, dezembro de 2018, p.585-611.

O Pastor Adélio é um cômico-satírico e crítico dos televangelistas ${ }^{9}$, os quais fazem uma leitura literal da Bíblia, desconsiderando o contexto em que foi escrita, e tomando-a com uma visão paradigmática. Um daqueles cômicos brasileiros, capaz de denunciar o burlesco, grotesco da sociedade brasileira, com uma verbosidade tumultuosa, tipicamente dos falantes do português do Brasil. Só na abertura do vídeo $A$ verdadeira história de Ló, é possível verificar todo esse jogo verbal, no discurso adotado pelo pastor Adélio, uma linguagem mais próxima da língua falada, que permite fugir de uma visão de mundo condicionada que revela aspectos da vida real, dos costumes, da cultura e da história que estavam encobertas pela rigidez das palavras adotada na Bíblia. Percebe-se essa aproximação com o fiel, pela linguagem, já no início do vídeo em que o Pastor inicia:

Olá meus irmãos, Pastor Adélio está de volta, atendendo aos pedidos. Muito obrigada a você que tem visto a minha pregação, que tem falado bem, que tem falado mal, pra caralho, tem visto, tá muito bem meu irmão. E, eu venho aqui novamente, meu irmão, responder esse acusador do satanás que vem novamente tentando vilipendiar a pessoa do pastor Adélio, meu irmão. Essa pessoa vem escrevendo no blog dele inverdades a meu respeito, e eu tô aqui pra responder novamente, meu irmão. Dessa vez, esse filho do satanás, veio falar que eu, um servo de Deus, meu irmão, que as minhas pregações aqui dentro da igreja são baseadas na bíblia. Ô meu irmão, que mentira, meu irmão. Eu nunca nem li a bíblia, meu irmão, não gosto, não entendo nada que tem ali dentro, meu irmão. O único livro que eu me baseio, que eu gosto, é o livro caixa aqui da igreja, meu irmão. Esse é um livro maravilhoso que eu gosto de ler. O único paraíso que tem aqui é o paraíso fiscal, que é onde eu mando meu dinheiro. Agora, vou ler bíblia pros meus clientes, meu irmão? Não dá, só tem coisa que não dá pra entender nada. Você quer ver um exemplo? (parte da transcrição do vídeo “a verdadeira história de Ló").

Nessa passagem inicial, é perceptível a utilização de uma linguagem chula que foge às regras gramaticais, na tentativa de se aproximar do público. Uma

\footnotetext{
${ }_{9}^{9}$ Televangelistas são os pastores que utilizam programas de televisão para transmitir a fé cristã para muitas pessoas.
} 
Religare, ISSN: 19826605, v.15, n.2, dezembro de 2018, p.585-611.

aproximação que assusta o espectador. Dessa forma, Bergson versa sobre o cômico nas situações e nas palavras, afirma que "é cômica toda combinação de atos e de acontecimentos que nos dê, inserida uma na outra a ilusão da vida e a sensação nítida de arranjo mecânico" (Bergson, 1980, p. 51).

Outro mecanismo fundamental do cômico de palavras é a transposição em que "obtém-se efeito cômico transpondo para outro tom a expressão natural de uma ideia" (BERGSON, 1980, p. 92). O autor faz referência também à degradação, mecanismo pelo qual uma coisa, antes respeitada, é apresentada de forma medíocre e ordinária. Infere-se aqui a própria passagem bíblica (Gênesis 19 - 20) que o humorista Marcio Américo traz na voz da personagem do Pastor Adélio.

[...] A história de Ló, meus irmãos, veja o absurdo disso. Ló era um sujeito que morava na cidade chamada Sodoma e Gomorra, é como se ele morasse ali entre a Augusta e a Frei Caneca, era viado pra todo lado, você pisava no rabo de um e o outro respondia, de tanto viado que tinha, e Ló morava ali, aí Deus pensou: Pô vou matar essa viadada toda. E mandou um anjo lá pra salvar Ló, porque Ló ele não ia destruir, Ló e a família dele ia salvar porque era gente boa, decente, tinham votado no Kassab, não, não vou matar o Ló. Aí chegou o anjo Em Sodoma, a hora que o anjo chega, meus irmão, a viadada ficou em polvorosa, ai tem bofe novo na cidade, e queria comer o anjo. Olha que absurdo, aí o que que Ló faz? Ló tem uma ideia. Olha que mensagem, meu irmão, o Ló sai na porta e fala assim pros viados de Sodoma: Viados de Sodoma, deixem o anjo em paz, ele é puro, ele assiste o programa da Eliana, ele acredita na revista Veja. É um anjo puro. Vocês querem comer cu do anjo, não façam isso, eu tenho uma proposta pra vocês, comam minha filha que é virgem, tá aqui minha filhinha, vem aqui dar pros meninos de Sodoma. Olha que pai amoroso, meu irmão. Qual que era o sobrenome de Ló? Nardoni? Mas o anjo, nesse momento, salvou a virgenzinha da filha de Ló, meu irmão.

Vejamos a baixo o texto fonte e comparemo-nos:

Bíblia de Jerusalém: Gênesis 19, 1-2910

${ }^{10}$ Bíblia de Jerusalém, Paulus, 4ㄹ impressão, 2006. SP p. 57-58 ( Gênesis 19, 1-29). 
Religare, ISSN: 19826605, v.15, n.2, dezembro de 2018, p.585-611.

1 Ao anoitecer, quando os dois Anjos chegaram a Sodoma, Ló estava sentado à porta da cidade. Logo que os viu, Ló se levantou ao seu encontro e prostrou-se com a face por terra. 2 E disse: " $\mathrm{Eu}$ vos peço, meus senhores! Descei à casa de vosso servo para aí passardes a noite e lavar-vos os pés; de manhã retornareis vosso caminho". Mas eles responderam: “Não, nós passaremos a noite em praça." 3 Tanto os instou que foram para sua casa e entraram. Preparou-lhes uma refeição, fez cozer pães ázimos, eles comeram. 4 Eles não tinham ainda deitado quando a casa foi cercada pelos homens da cidade, os homens de Sodoma, desde os jovens até os velhos, todo o povo sem exceção. 5 Chamaram Ló e lhe disseram: “Onde estão os homens que vieram para a tua casa esta noite? Traze-os para que deles abusemos." 6 Ló saiu à porta e, fechando-a atrás de si, 7 disse-lhes: "Suplico-vos, meus irmãos, não façais o mal! 8 Ouvi: tenho duas filhas que ainda são virgens; eu vo-las trarei: fazei-lhes o que bem vos parecer, mas a estes homens nada façais, porque entraram sob a sombra de meu teto." (Grifo meu)

Essa degradação está presente como, por exemplo, na apropriação do texto bíblico realizada pelo humorista, na personagem do Pastor Adélio, demonstrada no excerto acima. Deve-se, pois, também atentar para a instrumentalização do texto, o qual opera em um nível de mesclagem entre o que se entende por satírico, cômico e humor, esse em um sentido mais abrangente, para preencher as lacunas encontradas no texto bíblico, e assim construir uma personagem, o pastor.

Bergson (1980) aponta cinco formas de degradação, a saber: o exagero prolongado; a transposição, que se aplica ao valor das coisas; a comparação extrema, a oposição entre o real e o ideal, e a ironia. Portanto, é possível dizer que o cômico e o riso são para o crítico, respectivamente, a representação da falha dos valores positivos e sua sanção funcional que restabelece a ordem da vida e da sociedade. Nesse aspecto é que se insere a personagem do Pastor Adélio, pois, embora de forma agressiva, o pastor procura mostrar a seu público por meio do humor e da dessacralização do texto bíblico o que pode estar por traz do discurso dos evangelizadores da sociedade atual.

Comparando os excertos acima transcritos, o Pastor Adélio em contraponto com o texto bíblico, nos apresenta um confronto entre o humor e o cristianismo, esse confronto se dá na lacuna encontrada pelo pastor que está justamente no 
Religare, ISSN: 19826605, v.15, n.2, dezembro de 2018, p.585-611.

texto original. O texto original não explica, já não dá mais conta de expor o que de fato aconteceu. O humorista apropria-se do texto original, apresentando como anomalia essa "brecha".

Assim, no âmbito do desenvolvimento de um paradigma, a anomalia aparece como condição, como um fenômeno que evoca crises, que prepara o caminho para a busca de uma nova teoria que possa atender aos problemas, as necessidades postas em questão. É justamente nessas brechas que o Pastor Adélio vai se apegar para colocar em evidência uma gama de dúvidas sobre o próprio texto sagrado, ao observarmos as transcrições, acima, tanto perícope bíblica quanto do vídeo percebe-se a brecha deixada: Ló oferece a virgindade da filha (das filhas) aos homens de Gomorra em troca de proteção aos anjos. Transpondo para a vida real, seria possível um pai oferecer a virgindade de sua filha para "salvar" um homem? Talvez para a época em que o Velho Testamento tenha sido escrito isso fosse possível, mas nos paradigmas vigentes de família e religião isso não seria possível, nem aceitável. Então, essa lacuna encontrada é justamente o espaço da soleira descrito por Cacciari (2005, p. 14) em que diz: "Através da soleira somos acolhidos ou eliminados".

Nesse sentido, ao transitar entre essa lacuna, o pastor atravessa a fronteira, o limem, e se contamina com o lado oposto. E é justamente na soleira que se encontra o confim, em que segundo Cacciari (2005) seria o local onde dois domínios, duas ideias, convivem em um entrelugar, onde é possível a percepção das brechas.O Pastor Adélio provoca a transgressão ao colocar seu discurso lado a lado com o texto bíblico e consequentemente provocar o choque entre ambos. Podemos identificar outra fissura na história de Ló:

[...] Aí Deus, sempre Deus com as pegadinhas dele, Deus falou pra Ló: Vocês vão sair, meus irmãos? Mas vocês não olhem pra trás. Meu irmão, ia cair fogo do céu, meu irmão, eu olharia pra trás, eu paro pra ver briga de cachorro, meu irmão. Eu não vou parar pra ver fogo descendo do céu? Eu olho. Aí Deus, ...a mulher de ló olha pra trás, meu irmão. Lógico, caindo fogo do céu. Ele vai e transforma a mulher numa estátua de sal, meu irmão. Olha o desperdício. Resultado: tá lá o Ló viúvo, as filhas órfã, e toca, 
Religare, ISSN: 19826605, v.15, n.2, dezembro de 2018, p.585-611.

vai embora, vai morar aonde o Ló, perdido, perdeu a cidade por causa dos viados. Só por causa disso? Daqui a pouco vai querer o quê? Destruir o Rio de Janeiro? Aí Ló foi morar numa caverna com as duas filhas, meu irmão. Agora vem a cereja da história, meu irmão. Tão lá, Ló e as duas filhinhas virgens dele, morando na caverna, uma caverninha do $\mathrm{BNH}$, modestinha. Aí as filhas pensam assim: minha querida irmã, estamos só eu, você e nosso pai aqui, a nossa geração vai acabar aqui. Aí a outra teve uma ideia. Não vai não, a gente trepa com o papai e tem um filhinho dele. Olha que coisa abençoada, meu irmão, que lindo pra por nas escolas pras crianças, não é? Olá que coisa de Deus. Aí ela falou assim: mas papai não vai querer comer a gente. Mas a gente dá um porre nele. Aí pegaram e deram vinho pro pai beber. Onde elas acharam vinho nessa caverna? Compraram no Zé Colmeia? Deram o vinho pro pai e a primeira foi lá e transou com o pai mesmo, e diz o relato lá que no outro dia Ló não lembrava de nada. Porra, ela deu vinho ou uma maconha pra esse velho? ...caralho...que não lembrava. Aí no outro dia a segunda falou assim: eu vou dar pro papai também, porque vai que você não engravida. Aí a segunda foi lá, vinho no velho. Porra, o velho já devia se lembrar, noite passada elas me deram vinho e eu acordei pelado e melado.

Passagem bíblica:

23 Quando o sol se erguia sobre a terra e Ló entrou em Segor, 24 Iahweh fez chover, sobre Sodoma e Gomorra, enxofre e fogo vindos de Iahweh, 25 e destruiu essas cidades e toda a Planície, com todos os habitantes da cidade e a vegetação do solo. 26 Ora, a mulher de Ló olhou para trás e converteu-se numa estátua de sal. ${ }^{11}$

A origem dos moabitas e dos amonitas ${ }^{12}$ :

30 ó subiu de Segor e se estabeleceu na montanha com suas duas filhas, porque não ousava continuar em Segor. Ele se instalou numa caverna, ele e suas duas filhas. 31 A mais velha disse à mais nova: "Nosso pai é idoso e não há homem na terra que venha unir-se a nós, segundo o costume de todo o mundo. $32 \mathrm{Vem}$, façamos nosso pai beber vinho e deitemo-nos com ele; assim suscitaremos uma descendência de nosso pais. 33 Elas fizeram seu pai beber vinho, naquela noite, e a mais velha veio deitar-se junto de seu pai, que não precebeu nem quando ela se deitou, nem quando se levantou. 34 No dia seguinte, a mais velha disse à mais nova: "Na noite passada eu dormir com meu pai; façamolo beber vinho também nesta noite e vai deitar-se com ele; assim

${ }^{11}$ Bíblia de Jerusalém, Paulus, 4a impressão, 2006. SP p58 (Gênesis 19, 23-26)

12 Idem p58-59 (Gênesis 19, 30 - 38) 
Religare, ISSN: 19826605, v.15, n.2, dezembro de 2018, p.585-611.

suscitaremos uma descendência de nosso pai." 35 Elas fizeram seu pai beber vinho também naquela noite, e a menor deitou-se junto dele, que não percebeu nem quando ela se deitou, nem quando se levantou. 36 As duas filhas de Ló ficaram grávidas de seu pai. 37 A mais velha deu à luz um filho e o chamou de Moab; é o antepassado dos moabitas de hoje. 38 A mais nova deu também à luz um filho e chamou Bem-Ami; é o antepassado de Benê-Amon de hoje.

No contexto das citações, percebe-se o preenchimento da brecha enquanto método, na transcrição do vídeo do Pastor Adélio, citado acima, onde ele coloca uma série de dúvidas e questionamentos, que nada mais são de lacunas, brechas, as quais são preenchidas com o uso do humor, mas não um humor qualquer, um humor satírico e irônico com a intenção de provocar o choque e despertar riso: o fato de Ló ter sido advertido para não olhar para trás, assim como sua família, mas a mulher de Ló cai em tentação e olha para trás e acaba virando uma estátua de sal; é colocado em cheque como pode uma pessoa virar sal? Isso não é possível, pois não é racional pensar que alguém possa virar uma estátua de sal. Como conseguir não olhar para trás diante do que estava acontecendo? Quem não olharia? Outra situação é o fato de as filhas terem embebedado o pai e dormido com ele a ponto de engravidarem, que filha faria isso? No contexto atual seria improvável! Como embebedaram o pai, vinho de onde, como havia vinho na montanha?? A história não deixa claro como conseguiram vinho. Também, como o pai não se lembra de ter deitado com as filhas. Nessa lógica, os questionamentos vão preenchendo os espaços, as brechas deixadas pelo texto bíblico

Considera-se a acepção de Thomas Kuhn (1990), que a descoberta científica tem início no momento da consciência da anomalia que permite $o$ reconhecimento de que o paradigma vigente não dá conta, não atende mais as necessidades específicas de explicitar, de dar explicações acerca de uma série de questões, tanto de ordem teóricas, como metodológicas. Assim, é possível identificar tanto no texto bíblico quanto no discurso do Pastor Adélio um espaço de dúvida, do não dito. O texto bíblico deixa espaço para a personagem do Pastor Adélio criar seu discurso acompanhado de humor, justamente pelo contato entre 
Religare, ISSN: 19826605, v.15, n.2, dezembro de 2018, p.585-611.

a perícope bíblica com o discurso do pastor, que faz com que o confim, a soleira, o limem se choquem. Sendo assim, o contato entre o cristianismo e o humor abre uma lacuna carregada de questionamentos que, para o fiel-cristão, só é preenchido pela crença, pela fé, já para o Pastor Adélio é preenchido com humor, ironia e sátira.

Isso posto, cabe destacar mais alguns recursos utilizados pelas comédias que é a repetição. Repetir, ao que parece, leva o público às gargalhadas. No caso do vídeo $A$ verdadeira história de Ló esta técnica aparece de forma criativa e inesperada. No campo da linguagem, um dos exemplos mais pertinentes disso na fala do Pastor Adélio é a repetição da expressão "meu irmão" (35 vezes) ${ }^{13}$, uma gíria característica do carioca, que também faz parte dos jargões dos pastores neopentecostais e pentecostais. Outra expressão utilizada pela personagem do Pastor Adélio é "tô puto" ou "tô muito puto", é esta expressão que praticamente abre todos os vídeos do Pastor Adélio publicado na esquete virtual (são mais de 50). Nesse sentido, atenta-se aqui para o que diz Bergson (1980) que a repetição acontece quando o mesmo fato se repete em diferentes momentos ou situações. Com o uso insistente das mesmas palavras ou a repetição de frases feitas estereotipadas e reprimidas torna-se apropriada para a criação de uma personagem parodiada e risível. Assim, o humorista MarcioAmérico o faz, dessacralizando o texto considerado sagrado, bíblico, pela inserção de palavras chulas e que, muitas vezes, chegam a ofender o expectador.

${ }^{13}$ A "expressão "meu irmão" aparece 35 vezes no vídeo "A verdadeira história de Ló" que tem $6^{\prime} 07$. 


\section{Análise: Pastor Adélio: Detonando os Ursinhos Carinhosos}

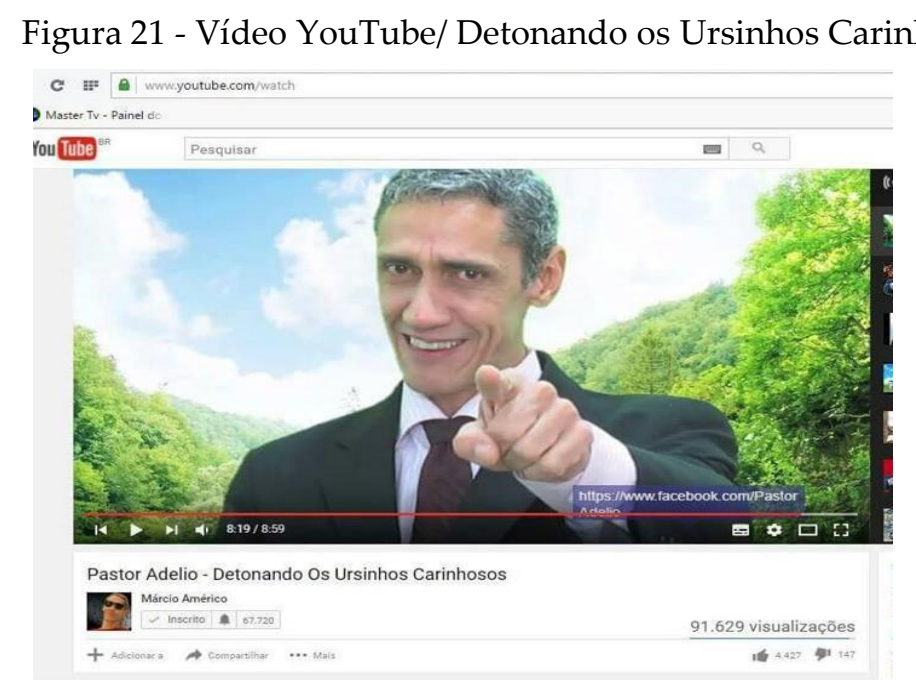

Fonte:https://www.youtube.com/watch?v=9FJH4bOAK6c\&index=1\&lis t=RD9FJH4bOAK6c. Acessado em 18/ 08/2015

No vídeo Detonando os Ursinhos Carinhosos o pastor Adélio direciona seu discurso aos fiéis, como em todos os vídeos, nele fala que está sendo julgado como uma pessoa insensível. No entanto, ele fica indignado com a acusação e diz:

[...]Meus irmãos, quero dizer a você que eu gostaria muito de ser uma pessoa insensível, ajudaria nos meus negócios, mas ainda não sou. Pra ser uma pessoa insensível mesmo eu precisaria acreditar em Deus e neste livro, a Bíblia.

A expressão de dúvida no discurso do Pastor é uma tentativa de inquietar o seu fiel e fazê-lo pensar nas condições e nas possibilidades de se acreditar ou não na Bíblia. A criação da dúvida na fala do Pastor nos traz elementos irônicos e satíricos. A sátira é irônica com relação à forma como o cristianismo roga para si a pretensão de deter a verdade religiosa com a Bíblia. A ironia fica clara quando a personagem admite não acreditar na Bíblia.

No contexto da citação acima, observa-se o que Bakhtin chamou de polêmica velada: 
Religare, ISSN: 19826605, v.15, n.2, dezembro de 2018, p.585-611.

[...] na polêmica velada, o discurso do autor está orientado para o seu objeto, como qualquer outro discurso; neste caso, porém, qualquer afirmação sobre o objeto é construída de maneira que, além de resguardar seu próprio sentido objetivo, ela possa atacar polemicamente o discurso do outro sobre o mesmo assunto e a afirmação do outro sobre o mesmo objeto. Orientado para o seu objeto, o discurso se choca no próprio objeto com o discurso do outro. (BAKHTIN, 1987, p. 169)

Como podemos notar na polêmica velada tem-se o ataque ao discurso e à afirmação do outro, como controvérsia violenta que caracteriza tal noção. É justamente o que a personagem do Pastor Adélio procura fazer, ao se posicionar ironicamente sobre a veracidade do que está escrito na Bíblia, contraponto o discurso da personagem, no caso aqui, com o da religião. Pode-se dizer que a polêmica no discurso do Pastor Adélio se sustenta nas lacunas deixadas pela Bíblia que oferecem as possibilidades de novas interpretações de acordo o paradigma bíblico vigente, esse que pode deixar de responder aos questionamentos apontados, suscitando assim novas interpretações.

Podemos identificar na personagem uma função revolucionária de dessacralização que se dá pelo rebaixamento dos antigos valores (MINOIS, 2003, p. 447). Ela baseia-se na divergência entre as normas de dois modos sociais de vida, historicamente determinados: daqueles que acreditam na religião e na Bíblia como representação de credo e daqueles que se dizem ateus, os ciberateísta $^{14}$, por exemplo, o humorista Marcio Américo, criador da personagem do Pastor Adélio. Podemos, nesse sentido, identificar no discurso da personagem uma prática ofensiva agressiva e contestadora.

[...] Pois essas Rello Kity de Cristo, meu irmão, se convencidas, elas deixarão o filho morrer e não darão uma transfusão de sangue. [...] Quer ver? Quando houve no Brasil o Massacre da Candelária, no Rio de Janeiro, onde oito crianças foram,

\footnotetext{
${ }^{14}$ Ciberateísta é a pessoa que utiliza a rede mundial de computadores para manifestar a sua descrença e ou contestar a crença do outro. O termo ciberateísmo fora cunhado pela professora doutora Salma Ferraz durante discussão em palestra na Semana de Letras da Universidade Federal de Santa Catarina no ano de 2016. Leitura pode ser aprofundada em minha dissertação de mestrado já citada nesse artigo.
} 
Religare, ISSN: 19826605, v.15, n.2, dezembro de 2018, p.585-611.

friamente, covardemente, assassinadas por policiais militares, os cristãos sensíveis, esses ursinhos carinhosos de Jesus, ficaram sensibilizados, mas se um massacre idêntico a esse ocorre na Bíblia, aí eles não só aceitam, como justificam e até fazem musiquinha.

Tomando a citação acima, o Pastor Adélio faz um questionamento acerca do que a sociedade aceita sem contestação e o que condena, como por exemplo: Quando ele fala sobre a transfusão de sangue que algumas pessoas não permitem, ele faz a inferência às testemunhas de Jeová, cuja doutrina não permite a transfusão de sangue, assim ele questiona, e aponta a brecha nos dogmas. $\mathrm{O}$ mesmo acontece quando ele fala da Chacina da Candelária, que ocorreu no dia 23 de julho de 1993, na qual foram mortos oito jovens - seis deles, menores de 18 anos. Quatro foram mortos a tiros, na escadaria da igreja. O Pastor Adélio vai fazer um paralelo com o que ele chamou de massacre na Bíblia, a história de Eliseu em II Reis, no Velho Testamento (II Reis: 2, 23-25) ${ }^{15}$ :

23.De lá subiu a Betel; ao subir pelo caminho, uns rapazinhos que saíram da cidade zombaram dele, dizendo: "Sobe, careca! Sobe, careca! 24. Eliseu virou-se, olhou para eles e os amaldiçoou e nome de Iahweh. Então saíram do bosque duas ursas e despedaçaram quarenta e dois deles. 25.Dali foi para o monte Carmelo e depois voltou para Samaria.

Nesse sentido, a personagem questiona o compadecimento dos "religiosos" com a Chacina da Candelária, mas não com o que aconteceu com as crianças, jovens, que ousaram em enxovalhar com Eliseu, o que lhes causou a morte provocada por Deus. O que se percebe nos discursos proferidos pela personagem do Pastor Adélio é a forma como se dá a interpretação, do saber ler e compreender diferentes formas de pensar o texto bíblico, que é tão complexo. E é justamente por ser um conjunto de textos entrelaçados, alguns leitores vão além do que está escrito e criam suas próprias interpretações, de acordo com o que

${ }^{15}$ Bíblia de Jerusalém, Paulus, $4^{\mathrm{a}}$ impressão, 2006. p. 509. (II Reis: 2, 23-25). 
Religare, ISSN: 19826605, v.15, n.2, dezembro de 2018, p.585-611.

lhes convém. O Pastor Adélio afirma em seu vídeo Detonando os Ursinhos Carinhos:

Não fica muito claro, meu irmão, porque é que os moleques não correram, porque eram só duas ursas e 42 moleques. Talvez eles tenham esperado em fila indiana ou tenham tirado senha, ou 41, 42 é você, não é você, vou te comer. ${ }^{16}$

O Pastor Adélio, no vídeo os ursinhos carinhosos, constitui a ironia e o humor no discurso por meio do exagero da interpretação do texto bíblico, deixando caminhos para contradições e novas interpretações. O nonsense das interpretações é que preenchem a brecha da crítica a algumas doutrinas que se utilizam do texto bíblico como forma de catequização, controle e enriquecimento ilícito. Assim, o exagero nos remete ao estereótipo de pastores pentecostais e neopentecostais de programas televisivos e aos que possuem suas igrejas.

No âmbito das citações acima, tanto na perícope bíblica quanto no vídeo percebe-se a brecha deixada, "como pode duas ursas matarem 42 crianças/adolescentes? Por que esperaram para ser mortos? Por que não correram, o que lhes impediu? Esses questionamentos desnudam as brechas, fazendo com que o confim, a soleira, o lime, se encontrem, se toquem, e assim se preencha de forma humorística, irônica, muitas vezes, satírica, permitindo uma criação performática de um pastor que só fala a verdade, o Pastor Adélio. Sendo assim, identificou-se que com o contato entre o cristianismo e o humor tem-se uma lacuna aberta, carregada de questionamentos que, para o fiel-cristão, só é preenchido pela crença, pela fé, já para o Pastor Adélio é preenchido com humor, ironia e sátira.

Contudo, Marcio Américo, com o seu estilo irreverente, manipula o discurso, creditado à Bíblia, para subverter o texto. É nessa subversão que o humorista cria um paradigma para o texto bíblico, dessacralizando-o, para preencher as brechas deixadas. É uma construção em que a linguagem opera muitas vezes de forma dupla, em recontar do texto original para, a partir desse

${ }^{16}$ Fragmento da transcrição do vídeo: Pastor Adélio - Os Ursinho Carinhoso. 
texto, construir seu objeto de discurso. Assim, é nessa construção que o humorista recorre ao seu conhecimento sociocultural acerca do objeto (que não muda) a ser referenciado, assim como o conhecimento de seu ouvinte/interlocutor sobre o assunto.

É importante dizer que os recurso utilizados pelo autor foram usados de forma proposital, pois o que todo cômico quer é chamar a atenção de seu público e Marcio Américo o faz por meio de vários artifícios, e a personagem do Pastor Adélio é um deles. Entretanto, cabe ressaltar que nem todos os pastores teleevangelistas são da forma que o autor descreve, muitos são comprometidos com o discurso bíblico e não fazem desse discurso um meio ilícito para obter lucros e tão pouco brincar com a fé dos cristãos. Assim, há que se destacar uma série de processos legais que o humorista vem respondendo, muitos deles por questões que supostamente ferirem a crença de determinados grupos religiosos. No entanto, segundo Marcio Américo, esses processos fazem parte da carreira do Pastor Adélio.

\section{Referências}

ADABIA, José P. T. A Bíblia Como Literatura. São Paulo: Vozes, 1999.

AGAMBEN, Giorgio. Signatura rerun: Sobre el método. Trad. Flavia Costa y Mercedes Ruvituso. Editorial Anagrama, S.A., Barcelona, 2010.

BERGSON, Henri. O riso: ensaio sobre a significação da comicidade. Trad. Ivone Castilho Benedetti. 1a ed. São Paulo: Martins Fontes, 1980. BÍBLIA DE JERUSALÉM. Português, 4⿳亠丷a reimpressão. São Paulo: Paulus, 2006.

Bíblia de Jerusalém, Paulus, 4⿳亠丷a impressão, 2006. p. 509.

BLOOM, Harold. Abaixo as verdades Sagradas - Poesia e crença desde a Bíblia até nossos dias. Trad. Alípio Correa de Franca Neto e Heitor Ferreira da Costa. São Paulo: Companhia das Letras, 1993.

BLOOM, Harold. Leio, logo existo. In: Revista Veja. São Paulo: Abril, ano 34, 31/01/2001, p. 11-15

BAKHTIN, Mikhail. Estética da criação verbal. Tradução de Paulo Bezerra. São Paulo: Martins Fontes, 2003.

BAKHTIN, Mikhail. Problemas da poética de Dostoiévski. Trad. Paulo Bezerra. 2. ed. Rio de Janeiro: Forense Universitária, 1997.

CACCIARI, Massimo. Nome de Lugares: confim, disponível em: <http://seer.fclar.unesp.br/letras/article/view/56/48>. Acessado em: 
13/04/2015 Original em italiano: "Nomi di luogo: confine", publicado em Revista aut aut, 299-300, settembre-dicembre 2000, Milano, p.73-79. Traduzido para o português por Giorgia Brazzarola e revisado por Silvana Gaspari.

FERRAZ, Salma. Martins, Patrícia Leonor. A arte do humor: "Pastor Adélio, o pastor mais sincero do mundo". Revista Teoliterária. V. 6 - 11 - 2016, p. 287 - 312.

FERRAZ, Salma. Martins, Patrícia Leonor; et al (org.). Teologia do Riso: humor e mau humor na Bíblia e no Cristianismo. Campina Grande - EDUEPB: 2017

FORSTER, E. M. Aspectos do romance. Editora Globo: Porto Alegre, 1969

KUHN, Thomas. A estrutura das revoluções científicas. Trad. Beatriz Vianna Doeira e Nelson Boeira. - 9. ed. - São Paulo: Perspectiva, 1990.

MARTINS, Patrícia Leonor. Ciberateísmo: religião e ateísmo em tempos de rede. Revista Teoliterária. V. 8 - 15 - 2018, p. 266 - 296.

MARTINS, Patrícia Leonor. Ciberateísmo: sátira e humor na personagem do pastor Adélio. Florianópolis - SC, Dissertação de Mestrado - UFSC, 2016.

MINOIS, Georges. História do Riso e do Escárnio. Trad. Maria Helena Ortiz Assumpção. São Paulo: UNESP, 2003.

MINOIS, Georges. História do Ateísmo: os descrentes no mundo ocidental, das origens aos nossos dias/ tradução Flávia Nascimento Falleiros, 1. Ed. - São Paulo: Editora Unesp, 2014.

MUECKE, D. C. Ironia e o irônico. Trad. Geraldo Gerson de Souza. São Paulo: Perspectiva, 1995.

SILVEIRA, André Luiz. Riso e subversão: O cristianismo pela Porta dos Fundos. Florianópolis - SC, Dissertação de Mestrado UFSC, 2016.

\section{Videos}

PASTOR ADÉLIO: Ló e suas filhas taradas. Disponível em: http://www.youtube.com/watch?v=y9g-YmLsgxE Acesso em: 12/01/2017.

PASTOR ADÉLIO: Detonando Os Ursinhos Carinhosos. Disponível em: https://www.youtube.com/watch?v=9FJH4bOAK6c . Acesso em: 12/01/2017. 